\title{
EFEKTIVTIAS PENYELENGGARAAN PELAYANAN PUBLIK PADA KANTOR DESA CANDIKUNING KECAMATAN BATURITI KABUPATEN TABANAN
}

\author{
Ni Wayan Sutiani \\ Jurusan Ilmu Administrasi Negara \\ Fakultas Ilmu Sosial dan Ilmu Politik Universitas Mahendradatta \\ Jl. Ken Arok No. 12, Peguyangan Denpasar \\ E-mail: sutianiwayan12@gmail.com
}

\begin{abstract}
Abstrak - Dari berapa pakar yang telah mengamati dan meneliti pelayanan publik, mereka memberikan kesimpulanya bahwa kualitas pelayanan publik di Indonesia masih sangat rendah. Secara umum penyebab dari kondisi rendahnya kualitas pelayanan publik masih berkisar pada rendahnya kualitas sumber daya manusia, penguasaan dalam teknik manajemen pelayanan publik yang kurang memadai serta masalah moral dan etika pelayanan publik yang belum mampu bersikap adil dan merata dalam member pelayanan pada masyarakat diyakini menjadi penyebab kurang memadainya kualitas pelayanan publik. Tujuan penelitian adalah untuk mengetahui penyelenggaraan pelayanan publik pada Kantor Desa Candikuning, Kecamatan Baturiti, Kabupaten Tabanan. Metode penelitian yang digunakan adalah menggunakan pendekatan penelitian survey dengan format penelitian Deskriptif. Populasi penelitian adalah seluruh anggota masyarakat di lingkungan Desa Candikuning, Kecamatan Baturiti Kabupaten Tabanan yang membutuhkan pelayanan administrasi umum. Penetapan sampel dapat disajikan data jumlah kunjungan ke Kantor Kepala Desa Candikuning, Kecamatan Baturiti Kabupaten Tabanan Kecamatan. dalam 3 bulan berturut-turut. Teknik penelitian yang diterapkan pada penelitian ini adalah menggunakan analisis deskriptif, yang dibantu dengan tabel tabulasi. Hasil penelitian dilihat dari variabel kualitas pelayanan publik di Kantor Kepala Desa Candikuning, Kecamatan Baturiti Kabupaten Tabanan dapat dikatakan telah memenuhi persyaratan sebagai pelayanan berkualitas. Dilihat dari variabel kepuasan masyarakat pelayanan publik di Kantor Kepala Desa Candikuningi, Kecamatan Baturiti Kabupaten Tabanan belum dapat memenuhi kepuasan masyarakat sebagai pengguna pelayanan. Adapun saran yang dapat disampaikan antara lain: Keterbukaan informasi tentang persyaratan administrasi teknis dan administrasi keuangan dalam memberikan pelayanan masih perlu mendapatkan perhatian, Keterbukaan informasi tentang kepastian waktu penyelesaian pada setiap urusan masih perlu mendapat perhatian.
\end{abstract}

Kata Kunci : Efektivitas, Pelayanan Publik.

\section{PENDAHULUAN}

Pembangunan pada dasarnya merupakan upaya yang dilakukan oleh masyarakat untuk memperbaiki keterbelakangan dan ketertinggalan dalam semua bidang kehidupan menuju suatu keadaan yang lebih baik dari pada keadaan sebelumnya. Tujuan pembangunan nasional bangsa Indonesia adalah mewujudkan masyarakat yang adil dan makmur baik material maupun spiritual. Pencapaian tujuan nasional di atas dilakukan dengan rangkaian upaya pembangunan berkesinambungan meliputi seluruh kehidupan masyarakat, bangsa dan negara yang dilaksanakan bersama oleh masyarakat dan pemerintah menuju terwujudnya masyarakat adil dan makmur. Masyarakat adalah pelaku utama pembangunan dan pemerintah berkewajiban untuk mengarahkan, membimbing serta menciptakan suasana yang menunjang.

Keberhasilan pembangunan nasional tidak lepas dari peran dan fungsi organisasi pemerintah yang mengemban tugas-tugas pemerintahan. Keberhasilan organisasi pemerintah dalam mencapai tujuan sangat mendukung tercapainya tujuan pembangunan nasional. Dalam rangka pencapaian tujuan nasional dan tujuan pembangunan nasional tersebut diperlukan peran serta 
Pegawai Negeri Sipil (PNS) sebagai unsur aparatur negara, abdi negara dan abdi masyarakat yang tugasnya adalah untuk melaksanakan pemerintahan dan tugas pembangunan.

Widjaja (1990: 35) menyebutkan bahwa Pegawai Negeri Sipil bukan hanya aparatur pemerintah, melainkan juga abdi negara dan abdi masyarakat yang pada dasarnya adalah pelayan masyarakat. Output dari pelaksanaan tugas adalah berupa jasa pelayanan kepada masyarakat. Pelayanan dikatakan efektif apabila aparat berhasil dalam melaksanakan tugasnya. Dengan kata lain keberhasilan tugas pemerintah dalam pembangunan nasional banyak tergantung pada kerja dan kemampuan pegawai negeri. Dari penjelasan tersebut kita dapat melihat bahwa kedudukan dan peranan pegawai negeri sangat penting dan menentukan keberhasilan pembangunan nasional.

Dari berapa pakar yang telah mengamati dan meneliti pelayanan publik, mereka memberikan kesimpulanya bahwa kualitas pelayanan publik di Indonesia masih sangat rendah. Secara umum penyebab dari kondisi rendahnya kualitas pelayanan publik masih berkisar pada rendahnya kualitas sumber daya manusia, penguasaan dalam teknik manajemen pelayanan publik yang kurang memadai serta masalah moral dan etika pelayanan publik yang belum mampu bersikap adil dan merata dalam member pelayanan pada masyarakat diyakini menjadi penyebab kurang memadainya kualitas pelayanan publik. Studi tentang kualitas pelayanan publik banyak di fokuskan pada hal tersebut. Diantara banyak faktor yang dapat mempengaruhi kepuasan pelanggan, faktor pelayanan diyakini sebagai faktor yang cukup dominan. Dengan kata lain jika kepuasan pelanggan akan menurun bahkan hilang sama sekali.

Islamy (1998:3) sebagai pakar ilmu administrasi negara, dengan pidato pengukuhan guru besarnya di Universitas Brawijaya dengan tegas menyatakan bahwa "salah satu unsur penting yang perlu mendapatkan perhatian pemerintah sebagai penyelenggara administrasi Negara di era reformasi pada saat ini adalah menanggapi semakin tajamnya kritik masyarakat atas rendahnya kual- itas pelayanan publik". Sedangkan di sisi lain masyarakat pada saat ini telah merasa melaksanakan kewajiban-kewajibannya, tetapi seringkali hak-haknya dipasung oleh aparat. Berpijak pada hasil penelitian para pakar di atas dan juga pandangan pemikiran yang mereka kemukakan tersebut, peneliti tertarik mengamati persoalan pelayanan publik pada lembaga Pemerintahan Kelurahan. Salah satu pemerintahan kepala desa yang ada di Tabanan tepatnya adalah Pemerintahan di Kantor Kepala Desa Candikuning, Kecamatan Baturiti, Kabupaten Tabanan.

Dari uraian latar belakang masalah, maka dapat dirumuskan permasalahan sebagai berikut:" Bagaimana penyelenggaraan pelayanan publik pada Kantor Kepala Desa Candikuning, Kecamatan Baturiti, Kabupaten Tabanan"?

\section{Metode Penelitian}

Penelitian ini mengambil lokasi di Kantor Kepala Desa Candikuning Kecamatan Baturiti, Kabupaten Tabanan. Penelitian ini menggunakan pendekatan penelitian survey dengan format penelitian Deskriptif. Populasi penelitian adalah seluruh anggota masyarakat di lingkungan Desa Candikuning, Kecamatan Baturiti yang membutuhkan pelayanan administrasi . Pengambilan anggota sampel dan juga objektifitas terhadap jawaban yang diberikan oleh responden, peneliti menarik anggota sampel secara bertahap yaitu pada setiap harinya akan diambil sebanyak 5 orang responden sebagai anggota sempel. Dalam kurun waktu 10 hari atau mungkin bisa lebih akan terkumpul sebanyak 50 orang responden sebagai anggota sempel. Teknik analisis data yang diterapkan pada penelitian ini adalah menggunakan analisis deskriptif.

\section{LANDASAN TEORI}

Tugas pelayanan publik adalah tugas memberikan pelayanan kepada umum tanpa membeda-bedakan dan diberikan secara cuma-cuma atau dengan biaya sedemikian rupa sehingga kelompok paling tidak mampu-pun mampu menjangkaunya. Tugas ini diemban oleh negara yang dilaksanakan melalui salah satu lengannya, yaitu lembaga eksekutif (pemerintah sebagai pelaksana). Tugas pembangunan adalah tugas untuk meningkatkan kesejahteraan ekonomi 
dari masyarakat. Tugas ini fokus kepada upaya membangun produktivitas dari masyarakat dan mengkreasikan nilai ekonomi atas produktivitas ekonomi tersebut. Tugas pembangunan ini menjadi misi dari organisasi ekonomi/dunia usaha atau lembaga bisnis. Sedangkan tugas pemberdayaan adalah peran untuk membuat setiap warga masyarakat mampu meningkatkan kualitas kemanusiaan dan kemasyarakatan. Tugas ini adalah tugas yang non-for-profit. Organisasi-organisasi nirlaba ciri utamanya adalah organisasi yang memiliki kompetensi pokok di bidang pemberdayaan.

Menurut Kantor Kementerian PAN, pelayanan publik adalah "segala bentuk pelayanan sektor publik yang dilaksanakan aparat pemerintah dalam bentuk barang dan atau jasa, yang sesuai dengan kebutuhan masyarakat dan peraturan perundang-undangan" (Lihat Naskah Akademik RUU tentang Pelayanan Publik). Sedangkan menurut Komisi Hukum Nasional dalam kajiannya merilis, Pelayanan Publik adalah "suatu kewajiban yang diberikan oleh Konstitusi atau Undang-undang kepada Pemerintah untuk memenuhi hak-hak dasar warga negara atau penduduk atas suatu pelayanan (publik)."

Khusus terhadap tugas pelayanan umum (publik) yang diselenggrakan pemerintah tersebut, secara umum dapat dikelompokkan lagi menjadi tiga macam yaitu: Pertama, pelayanan primer. Pelayanan primer adalah pelayanan yang 'paling mendasar' atau dapat disebut juga 'pelayanan minimum', seperti: pelayanan kewargaan, pelayanan kesehatan, pelayanan pendidikan, dan pelayanan ekonomi. Kedua, pelayanan sekunder yaitu pelayanan pendukung namun bersifat kelompok spesifik. Dan ketiga, pelayanan tersier yaitu pelayanan yang berhubungan secara tidak langsung kepada publik.

Terhadap perumusan kebijakan dalam pelayanan minimum sejak awal harus dirumuskan standar pokok pelaksanaan dan standar pokok audit implementasi kebijakannya. Penentuan standar pokok pelaksanaan dan standar pokok audit implementasinya dikelompokkan lagi dalam tiga isu utama, yaitu:
1. Kebijakan dari pelayanan minimum, yaitu kebijakan yang sudah ada dan kebijakan yang akan dibuat.

2. Implementasi pelayanan minimum, terdiri dari; manusia (SDM), organisasi, infrastruktur, mekanisme, dan pembiayaan.

3. Nilai pelayanan minimum, yang terdiri dari indikator; akuntabilitas, transparansi, keadilan, dan responsivitas.

Simpulan yang dapat diambil adalah bahwa tugas pemberian pelayanan minimum ini merupakan tugas pokok yang diemban oleh pemerintah dan sekaligus menjadi tolok ukur akan keberhasilan kinerja pemerintahnya. Karena itu tugas pelayanan minimum ini harus dijadikan komitmen politiknya, yang kemudian disusun dalam rancangan strategis, sistem evaluasi, sistem pendampingan, dan sitem audit secara baik dan proporsional. Satu kata kunci untuk menilai seberapa jauh pemerintah sudah melakukan standar pelayanan minimum sesuai dengan misi, standar acuan, dan standar audit terhadap tugas yang diembannya adalah terletak pada nilai akuntabilitas, karena akuntabilitas adalah ruh/jiwa dari prinsip good governance.

\section{PEMBAHASAN}

\section{Dilihat dari Variabel Prosedur dan Tata cara Pelayanan}

Dari hasil pengamatan terhadap 50 orang responden yang terjaring sebagai sampel pada penelitian ini, dapat diketemukan informasi yang diberikan oleh para responden tersebut, terhadap tiga aspek yang dinilai sebagai dimensi penilaian prosedur dan tata cara pelayanan aadalah seperti tersebut pada tabel berikut ini. 
Tabel 1

Penilaian Responden Terhadap Prosedur dan Tatacara Pelayanan

\begin{tabular}{|c|l|c|c|c|c|}
\hline \multirow{2}{*}{ No } & \multirow{2}{*}{ Aspek yang Dinilai } & \multicolumn{2}{|c|}{$\begin{array}{c}\text { Jawaban } \\
\text { (orang) }\end{array}$} & \multicolumn{2}{c|}{ Persentase } \\
\cline { 3 - 6 } & & Ya & Tdk & Ya & Tdk \\
\hline 1 & $\begin{array}{l}\text { Adanya keterbukaan } \\
\text { informasi tentang } \\
\text { rangkaian unit-unit } \\
\text { kerja yang akan } \\
\text { ditempuh oleh } \\
\text { penerima pelayanan di } \\
\text { Kantor ini. }\end{array}$ & 27 & 23 & 54 & 46 \\
\hline 2 & $\begin{array}{l}\text { Adanya kejelasan dan } \\
\text { kepastian para petugas } \\
\text { yang akan } \\
\text { bertanggung jawab } \\
\text { menangani urusan } \\
\text { anda di Kantor ini. }\end{array}$ & 35 & 15 & 70 & 30 \\
\hline 3 & $\begin{array}{l}\text { Adanya prosedur dan } \\
\text { tatacara pelayanan } \\
\text { yang ditempuh oleh } \\
\text { pengguna pelayanan } \\
\text { di Kantor sudah } \\
\text { sederhana. }\end{array}$ & 33 & 17 & 66 & 34 \\
\hline
\end{tabular}

Sumber:Lampiran 2, Tabulasi Tabel A Nomor 1.

Jika diperhatikan angka-angka pada tabel di atas, maka dapat dijelaskan penilaian responden terhadap prosedur dan tata cara pelayanan, yang dilihat dari 3 aspek penilaian adalah sebagai berikut:

a. Sebagian besar responden 54\% menyatakan telah terdapat adanya keterbukaan informasi tentang rangkaian unit-unit kerja yang akan ditempuh oleh pengguna pelayanan dan sisanya sebanyak $46 \%$ dari para responden menyatakan belum terdapat adanya keterbukaan informasi tersebut.

b. Sebagian besar responden $70 \%$ menyatakan telah terdapat adanya kejelasan dan kepastian para petugas yang bertanggungjawab menangani urusan penggunaan pelayanan dan $30 \%$ dari para responden menyatakan belum adanya kejelasan dan kepastian tersebut.

c. Sebagian besar responden $66 \%$ menyatakan telah terdapat adanya kesederhanaan prosedur dan tatacara pelayanan yang ditempuh oleh pengguna pelayanan dan $34 \%$ menyatakan hal ini belum sederhana.

\section{Dilihat dari Variabel Persyaratan Administrasi}

Dari 50 orang responden yang terjaring sebagai sampel pada penelitian ini, mereka memberikan informasi terhadap tiga aspek yang dinilai sebagai dimensi persyaratan administrasi, adalah seperti tabel berikut ini.

Tabel 2

Penilaian Responden Terhadap

\begin{tabular}{|c|l|c|c|c|c|}
\hline No & Aspek yang Dinilai & \multicolumn{2}{|c|}{$\begin{array}{c}\text { Jawaban } \\
\text { (orang) }\end{array}$} & \multicolumn{2}{|c|}{ Persentase } \\
\cline { 3 - 6 } & & Ya & Tdk & Ya & Tdk \\
\hline 1 & $\begin{array}{l}\text { Adanya keterbukaan } \\
\text { informasi tentang } \\
\text { persyaratan } \\
\text { administrasi teknis } \\
\text { dan administrasi } \\
\text { keuangan kepada } \\
\text { pengguna pelayanan } \\
\text { di kantor ini }\end{array}$ & 25 & 25 & 50 & 50 \\
\hline 2 & $\begin{array}{l}\text { Adanya persyaratan } \\
\text { administrasi teknis } \\
\text { pada setiap urusan } \\
\text { di Kantor ini, sudah } \\
\text { mudah dipenuhi } \\
\text { oleh pengguna } \\
\text { pelayanan. }\end{array}$ & 25 & 25 & 50 & 50 \\
\hline 3 & $\begin{array}{l}\text { Adanya persyaratan } \\
\text { administrasi } \\
\text { keuangan pada } \\
\text { setiap urusan di } \\
\text { Kantor ini, dapat } \\
\text { terjangkau oleh } \\
\text { pengguna } \\
\text { pelayanan. }\end{array}$ & 29 & 21 & 58 & 42 \\
\hline
\end{tabular}

Sumber: Lampiran 2, Tabulasi Tabel A Nomor 2.

Jika diperhatikan angka-angka pada tabel di atas, maka dapat dijelaskan penilaian responden terhadap persyaratan administrasi dan pelayanan, yang dilihat dari 3 aspek penilaian adalah sebagai berikut:

a. Para responden yang memberikan penilaian terhadap adanya keterbukaan informasi tentang persyaratan administrasi teknis dan administrasi keuangan kepada pengguna pelayanan $50 \%$ dan $50 \%$ lagi menyatakan belum ada keterbukaan atas informasi tersebut.

b. Para responden yang memberikan penilaian terhadap adanya persyaratan administrasi teknis 50\% dan 50\% lagi yang menyatakan belum ada persyaratan administrasi teknis.

c. Sebagian besar responden $58 \%$ menyatakan telah terdapat adanya persyaratan administrasi keuangan mudah dijangkau oleh pengguna pelayanan. Dan sisanya sebanyak $42 \%$ menyatakan hal ini belum mudah dijangkau oleh pengguna pe- 
layanan.

3. Dilihat dari Variabel Waktu Pelayanan

Dari 50 orang responden yang terjaring se bagai sampel pada penelitian ini, mereka memberikan informasi terhadap dua aspek yang dinilai sebagai dimensi variabel waktu pelayanan, adalah seperti tabel berikut ini.

Tabel 3

Penilaian Responden Terhadap Waktu Pelayanan

\begin{tabular}{|c|l|c|c|c|c|}
\hline No & Aspek yang Dinilai & \multicolumn{2}{|c|}{$\begin{array}{l}\text { Jawaban } \\
\text { (orang) }\end{array}$} & \multicolumn{2}{c|}{ Persentase } \\
\cline { 3 - 6 } & & Ya & Tdk & Ya & Tdk \\
\hline 1 & $\begin{array}{l}\text { Apakah anda sudah } \\
\text { melihat adanya } \\
\text { ketebrukaan } \\
\text { informasi tentang } \\
\text { kepastian waktu } \\
\text { penyelesaian pada } \\
\text { setiap urusan di } \\
\text { Kantor ini? }\end{array}$ & 18 & 32 & 36 & 64 \\
\hline 2 & $\begin{array}{l}\text { Apakah anda sudah } \\
\text { merasakan adanya } \\
\text { ketepatan waktu } \\
\text { penyelesaian pada } \\
\text { setiap urusan di } \\
\text { Kantor ini? }\end{array}$ & 16 & 34 & 32 & 68 \\
\hline
\end{tabular}

Sumber: Lampiran 2, Tabulasi Tabel A Nomor 3.

Jika diperhatikan angka-angka pada tabel di atas, maka dapat dijelaskan penilaian responden terhadap waktu pelayanan, yang dilihat dari 2 aspek penilaian adalah sebagai berikut:

a. Sebagian besar responden $64 \%$ menyatakan belum terdapat adanya keterbukaan informasi tentang kepastian waktu penyelesaian urusan pada setiap pelayanan yang akan dilakukan oleh pengguna layanan. Sisanya $36 \%$ dari para responden menyatakan adanya ketebrukaan informasi tersebut.

b. Sebagian besar responden $66 \%$ menyatakan belum terdapat adanya ketepatan waktu dalam menyelesaikan setiap urusan yang dilakukan oleh pengguna pelayanan dalam berurusan di kantor ini. Sisanya 34\% dari para responden tersebut menyatakan terdapat adanya ketepatan waktu dalam mereka menyelesaikan urusannya.

\section{Dilihat dari Variabel Perilaku Petu- gas Pemberi Pelayanan}

Dari 50 orang responden yang terjaring sebagai sampel pada penelitian ini, mereka memberikan informasi terhadap tiga aspek yang dinilai sebagai dimensi variabel perilaku petugas pemberi pelayanan, adalah seperti tabel berikut ini.

Tabel 4

Penilaian Responden Terhadap Perilaku Petugas Pemberi Pelayanan

\begin{tabular}{|c|l|c|c|c|c|}
\hline \multirow{2}{*}{ No } & \multicolumn{1}{|c|}{$\begin{array}{c}\text { Aspek yang } \\
\text { Dinilai }\end{array}$} & \multicolumn{2}{|c|}{$\begin{array}{c}\text { Jawaban } \\
\text { (orang) }\end{array}$} & \multicolumn{2}{c|}{ Persentase } \\
\cline { 3 - 6 } & & Ya & Tdk & Ya & Tdk \\
\hline 1 & $\begin{array}{l}\text { Adanya } \\
\text { kemudahan } \\
\text { pengguna } \\
\text { pelayanan untuk } \\
\text { menemukan para } \\
\text { petugas yang } \\
\text { bertanggung jawab } \\
\text { pada setiap urusan } \\
\text { di Kantor ini. }\end{array}$ & 34 & 16 & 68 & 32 \\
\hline 2 & $\begin{array}{l}\text { Adanya keramah } \\
\text { tambahan dan } \\
\text { kesopanan para } \\
\text { petugas pemberi } \\
\text { pelayanan pada } \\
\text { setiap urusan di } \\
\text { Kantor ini. }\end{array}$ & 42 & 8 & 84 & 16 \\
\hline 3 & $\begin{array}{l}\text { Adanya sikap } \\
\text { tanggap para } \\
\text { petugas pemberi } \\
\text { pelayanan } \\
\text { terhadap pengguna } \\
\text { pelayanan pada } \\
\text { setiap urusan di } \\
\text { kantor ini. }\end{array}$ & 32 & 18 & 64 & 36 \\
\hline
\end{tabular}

Sumber: Lampiran 2, Tabulasi Tabel ANomor 4.

Jika diperhatikan angka-angka pada tabel di atas, maka dapat dijelaskan penilaian responden terhadap perlaku petugas pemberi pelayanan, yang dilihat dari 3 aspek penilaian adalah sebagai berikut:

a. Sebagian besar responden $68 \%$ menyatakan telah terdapat adanya kemudahan untuk menemukan para petugas yang bertanggung jawab untuk menyelesaikan urusan yang diperlukan oleh pengguna pelayanan dan $32 \%$ dari para responden menyatakan belum terdapat adanya kemudahan untuk menemukan para petugas tersebut.

b. Keseluruhan responden $84 \%$ men- 
yatakan telah terdapat adanya keramah-tamahan dan kesopanan para petugas pemberi pelayanan dan $16 \%$ dari para responden menyatakan belum terdapat keramah-tamahan dan kesopanan para petugas pemberi pelayanan.

c. Sebagian besar responden $64 \%$ menyatakan telah terdapat adanya sikap tanggap para petugas pemberi pelayanan, $36 \%$ menyatakan para petugas tersebut tidak tanggap kepada para pengguna pelayanan yang sedang berurusan di kantor ini.

\section{Dilihat dari Variabel Jaminan Keamanan dan Kenyamanan}

Dari 50 orang responden yang terjaring sebagai sampel pada penelitian ini, mereka memberikan informasi terhadap lima aspek yang dinilai sebagai dimensi variabel keamanan dan kenyamanan pelayanan, adalah seperti tabel berikut ini.

Tabel 5

Penilaian Responden Terhadap Jaminan Keamanan dan Kenyamaan Pelayanan

\begin{tabular}{|c|l|c|c|c|c|}
\hline \multirow{2}{*}{ No } & Aspek yang Dinilai & \multicolumn{2}{|c|}{$\begin{array}{l}\text { Jawaban } \\
\text { (orang) }\end{array}$} & \multicolumn{2}{|c|}{ Persentase } \\
\cline { 3 - 6 } & & Ya & Tdk & Ya & Tdk \\
\hline 1 & $\begin{array}{l}\text { Adanya } \\
\text { ketersediaan ruang } \\
\text { tunggu yang } \\
\text { nyaman bagi } \\
\text { pengguna } \\
\text { pelayanan di } \\
\text { Kantor ini. }\end{array}$ & 35 & 15 & 70 & 30 \\
\hline 2 & $\begin{array}{l}\text { Adanya } \\
\text { ketersediaan } \\
\text { tempat parkir yang } \\
\text { aman bagi } \\
\text { pengguna } \\
\text { pelayanan di } \\
\text { Kantor ini. }\end{array}$ & 40 & 10 & 80 & 20 \\
\hline 3 & $\begin{array}{l}\text { Adanya bukti-bukti } \\
\text { tanda terima, } \\
\text { sebagai tanda } \\
\text { penolakan berkas } \\
\text { ataupun } \\
\text { persetujuan } \\
\text { pemrosesan berkas } \\
\text { bagi pengguna } \\
\text { pelayanan di } \\
\text { Kantor ini. }\end{array}$ & 19 & 31 & 38 & 62 \\
\hline
\end{tabular}

\begin{tabular}{|c|l|c|c|c|c|}
\hline 4 & $\begin{array}{l}\text { Adanya bukti tanda } \\
\text { terima pembayaran } \\
\text { bagi pengguna } \\
\text { pelayanan di } \\
\text { Kantor ini. }\end{array}$ & 16 & 34 & 32 & 68 \\
\hline 5 & $\begin{array}{l}\text { Adanya hasil } \\
\text { penyelesaian } \\
\text { urusan yang } \\
\text { diterima oleh } \\
\text { pengguna } \\
\text { pelayanan, telah } \\
\text { dapat terbebaskan } \\
\text { dari kesalahan di } \\
\text { Kantor ini. }\end{array}$ & 20 & 30 & 40 & 60 \\
\hline
\end{tabular}

Sumber: Lampiran 2, Tabulasi Tabel A Nomor 5.

Jika diperhatikan angka-angka pada tabel di atas, maka dapat dijelaskan penilaian responden terhadap keamanan dan kenyamanan pelayanan, yang dilihat dari 5 aspek penilaian adalah sebagai berikut:

a. Sebagian besar responden $70 \%$ menyatakan telah merasakan adanya ketersediaan ruang tunggu yang nyaman bagi pengguna pelayanan di Kantor ini, sisanya $30 \%$ dari para responden menyatakan belum merasakan adanya ketersediaan ruang tunggu yang nyaman bagi pengguna pelayanan di kantor ini.

b. Sebagian besar responden $80 \%$ menyatakan telah merasakan adanya ketersediaan parkir yang amann bagi pengguna pelayanan di Kantor ini, sisanya $20 \%$ dari para responden menyatakan belum merasakan adanya ketersediaan parkir yang aman bagi pengguna pelayanan di kantor ini.

c. Sebagian besar responden $38 \%$ menyatakan belum merasakan adanya ketersediaan bukti-bukti tanda terma, sebagai tanda penolakan berkas ataupun persetujuan pemrosesan berkas bagi pengguna pelayanan Kantor ini. Sisanya $62 \%$ menyatakan telah merasakan adanya bukti-bukti tanda terima sebagai tanda penolakan berkas ataupun persetujuan pemrosesan berkas bagi pengguna pelayanan di Kantor ini.

d. Sebagian besar responden $68 \%$ 
menyatakan belum melihat adanya bukti tanda terima pembayaran bagi pengguna pelayanan di Kantor ini, sisanya $32 \%$ menyatakan telah melihat adanya bukti-bukti tanda terima pembayaran tersebut.

e. Sebagian besar responden $60 \%$ menyatakan belum merasakan adanya hasil penyelesaian urusan yang diterima oleh pengguna pelayanan, telah dapat terbebaskan dari kesalahan di Kantor ini. sisanya $40 \%$ menyatakan telah merasakan adanya hasil penyelesaian urusan yang diterima oleh pengguna pelayanan, telah dapat terbebaskan dari kesalahan.

\section{Hasil Pengamatan Terhadap Kepuasan Pelanggan}

1) Dilihat dari Variabel Kepuasan Terhadap Prosedur dan Tatacara Pelayanan

Ada tiga aspek yang dijadikan dasar penilaian rasa puas dan tidak pusanya masyarakat terhadap prosedur dan tata cara pelayanan. Aspek-aspek tersebut meliputi: 1) keterbukaan informasi tentang rangkaian unit-unit kerja yang telah ditempuh oleh pengguna pelayanan, 2) Kejelasan dan kepastian para petugas yang bertanggung jawab menangani urusan pengguna pelayanan, dan 3) Kesederhanaan prosedur dan tatacara pelayanan yang ditempuh oleh pengguna pelayanan.

Hasil pengamatan terhadap rasa puas dan tidak puasnya para responden terhadap prosedur dan tatacara pelayanan yang diselenggarakan oleh Kantor Kepala Desa Candikuning, Kecamatan Baturiti, Kabupaten Tabanan dapat ditunjukkan seperti tersebut pada tabel di bawah ini.
Tabel 6

Pernyataan Kepuasan Responden Terhadap Prosedur Dan Tata Cara Pelayanan

\begin{tabular}{|c|l|c|c|c|c|}
\hline No & \multirow{2}{*}{\begin{tabular}{c} 
Aspek yang Dinilai \\
\cline { 3 - 5 }
\end{tabular}} & \multicolumn{2}{|c|}{$\begin{array}{c}\text { Jawaban } \\
\text { (orang) }\end{array}$} & \multicolumn{2}{|c|}{ Persentase } \\
\hline 1 & $\begin{array}{l}\text { Yagaimanakah } \\
\text { perasaan anda } \\
\text { terhadap } \\
\text { ketebrukaan } \\
\text { informasi tentang } \\
\text { rangkaian unit-unit } \\
\text { kerja yang anda } \\
\text { telah tempuh di } \\
\text { Kantor ini? }\end{array}$ & 27 & 23 & 54 & 46 \\
\hline 2 & $\begin{array}{l}\text { Bagaimanakah } \\
\text { perasaan anda } \\
\text { terhadap kejelasan } \\
\text { dan kepastian para } \\
\text { petugas yang } \\
\text { bertanggung jawab } \\
\text { menangani urusan } \\
\text { anda di Kantor ini? }\end{array}$ & 37 & 13 & 74 & 26 \\
\hline 3 & $\begin{array}{l}\text { Bagaimanakah } \\
\text { perasaan anda } \\
\text { ternadap } \\
\text { kesederhanaan } \\
\text { prosedur dan } \\
\text { tatacara pelayanan } \\
\text { nyang anda telah } \\
\text { tempuh di Kantor } \\
\text { ini? }\end{array}$ & 33 & 17 & 66 & 34 \\
\hline
\end{tabular}

Sumber: Lampiran 2, Tabulasi Tabel B Nomor 1

Dari 50 orang responden yang menjadi sampel penelitian, sebagaimana ditunjukkan pada tabel hasil penelitian di atas, dapat diketahui bahwa:

a. Sebanyak $54 \%$ diantaranya memberikan pernyataan telah merasa puas dengan keterbukaan informasi tentang rangkaian unit-unit kerja yang mereka tempuh di Kantor ini dan $46 \%$ menyatakan tidak puas.

b. Sebanyak $74 \%$ diantaranya memberikan pernyataan telah merasa puas dengan kejelasan dan kapasitas para petugas yang bertanggung jawab menangani urusan mereka dan $26 \%$ diantaranya menyatakan tidak puas.

c. Sebanyak $66 \%$ diantaranya memberikan pernyataan telah merasa puas dengan kesederhanaan prosedur dan tata cara pelayanan yang mereka tempuh di Kantor ini dan sebanyak 34\% diantaranya menyatakan tidak puas. 
2) Dilihat dari Variabel Kepuasan Terhadap Persyaratan Administrasi

Dalam mengamati rasa puas dan tidak puasnya pengguna pelayanan terhadap variabel persyaratan administrasi, ada tiga aspek yang dijadikan standar penilaian, yaitu: 1) aspek keterbukaan informasi tentang persyaratan administrasi teknis dan administrasi keuangan yang harus dipenuhi oleh pengguna pelayanan, 2) aspek kemudahan dipenuhinya persyaratan administrasi teknis pada setiap urusan oleh pengguna pelayanan dan 3) aspek kemudahan persyaratan administrasi keuangan untuk dapat dijangkau oleh pengguna pelayanan.

Hasil pengamatan tentang rasa puas dan tidak puasnya para responden terhadap persyaratan administrasi pelayanan yang ditetapkan oleh Kantor Kepala Desa Candikuning Kecamatan Baturiti, Kabupaten Tabanan di dalam memberikan pelayanan dapat ditunjukkan pada tabel di bawah ini. Dari 50 orang responden yang menjadi sampel penelitian, sebagaimana ditunjukkan pada tabel hasil penelitian di atas, dapat diketahui bahwa:

a. Sebanyak $40 \%$ diantaranya memberikan pernyataan telah merasa puas dengan keterbukaan informasi tentang persyaratan administrasi teknis dan administrasi keuangan yang diberikan di Kantor ini dan $60 \%$ diantaranya memberikan pernyataan tidak puas

b. Sebanyak $54 \%$ diantaranya memberikan pernyataan telah merasa puas dengan kemudahan dipenuhinya persyaratan administrasi teknis pada setiap urusan yang ada di Kantor ini dan sisanya hanya $46 \%$ yang menyatakan tidak puas.

c. Sebanyak $48 \%$ diantaranya memberikan pernyataan telah merasa puas dengan persyaratan administrasi keuangan pada setiap urusan, yang dapat terjangkau oleh pengguna pelayanan di kantor ini dan sebanyak 52\% diantaranya menyatakan tidak puas.

\section{3) Dilihat dari Variabel Kepuasan Terh- adap Waktu Pelayanan}

Dalam mengamati rasa puas dan tidak puasnya pengguna pelayanan terhadap variabel waktu pelayanan, ada dua aspek yang dijadikan standar penilaian, yaitu: 1) aspek keterbukaan informasi tentang waktu penyelesaian setiap urusan dan, 2) aspek ketepatan waktu penyelesaian setiap urusan. Hasil pengamatan pengamatannya dapat ditunjukkan seperti pada tabel di bawah ini.

\section{Tabel 7}

Pernyataan Kepuasan Responden TerhadapWaktu Pelayanan

\begin{tabular}{|c|l|c|c|c|c|}
\hline \multirow{2}{*}{ No } & \multicolumn{1}{|c|}{$\begin{array}{c}\text { Aspek yang } \\
\text { Dinilai }\end{array}$} & \multicolumn{2}{|c|}{$\begin{array}{c}\text { Jawaban } \\
\text { (orang) }\end{array}$} & \multicolumn{2}{c|}{ Persentase } \\
\cline { 3 - 6 } & & \multicolumn{1}{|c|}{ Ya } & Tdk & Ya & Tdk \\
\hline 1 & $\begin{array}{l}\text { Apakah anda } \\
\text { sudah merasa puas } \\
\text { terhadap } \\
\text { keterbukaan } \\
\text { informasi tentang } \\
\text { kepastian waktu } \\
\text { penyelesaian } \\
\text { setiap urusan di } \\
\text { Kantor ini? }\end{array}$ & 18 & 32 & 36 & 64 \\
\hline 2 & $\begin{array}{l}\text { Apakah anda } \\
\text { sudah merasa puas } \\
\text { terhadap ketepatan } \\
\text { waktu } \\
\text { penyelesaian } \\
\text { setiap urusan di } \\
\text { Kantor ini? }\end{array}$ & 16 & 34 & 32 & 68 \\
\hline
\end{tabular}

Sumber: Lampiran 3, Tabulasi Tabel B Nomor 3

Dari 50 orang responden yang menjadi sampel penelitian, sebagaimana ditunjukkan pada tabel hasil penelitian di atas, dapat diketahui bahwa:

a. Sebanyak $30 \%$ diantaranya memberikan pernyataan telah merasa puas dengan keterbukaan informasi tentang kepastian waktu penyelesaian setiap urusan di Kantor ini dan sisanya sebanyak $64 \%$ diantaranya memberikan pernyataan tidak puas

b. Sebanyak $32 \%$ diantaranya memberikan pernyataan telah merasa puas dengan ketepatan waktu penyelesaian setiap urusan di Kantor ini dan sisanya hanya $68 \%$ diantara mereka menyatakan tidak puas.

\section{4) Dilihat dari Variabel Kepuasan Ter- hadap Perilaku Petugas Pemberi Pe- layanan}

Dalam mengamati rasa puas dan tidak puasnya pengguna pelayanan terhadap variabel waktu pelayanan, ada dua aspek yang dijadikan standar penilaian, yaitu: 1) aspek kemudahan untuk menemukan para petugas yang bertanggung jawab menan- 
gani setiap urusan, 2) aspek keramahtamahan dan kesopanan para petugas pemberi pelayanan, serta 3) aspek sikap ketanggapan daripada para petugas pemberi pelayanan.

Hasil pengamatan penelitian ini terhadap pernyataan rasa puas dan tidak puasnya para responden tentang variabel perilaku petugas pemberi pelayanan di Kantor Kepala Desa Candikuning, Kecamatan Baturiti Kabupaten Tabanan di dalam mereka memberikan pelayanan kepada para pengguna pelayanan dapat ditunjukkan seperti pada tabel di bawah ini.

Tabel 8

Pernyataan Kepuasan Responden Terhadap Perilaku Petugas Pemberi Pelayanan

\begin{tabular}{|c|c|c|c|c|c|}
\hline \multirow[t]{2}{*}{ No } & \multirow{2}{*}{ Aspek yang Dinilai } & \multicolumn{2}{|c|}{$\begin{array}{c}\text { Jawaban } \\
\text { (orang) }\end{array}$} & \multicolumn{2}{|c|}{ Persentase } \\
\hline & & Ya & Tdk & Ya & Tdk \\
\hline 1 & $\begin{array}{l}\text { Bagaimanakah } \\
\text { perasaan anda } \\
\text { terhadap } \\
\text { kemudahan untuk } \\
\text { menemukan para } \\
\text { petugas yang } \\
\text { bertanggung jawab } \\
\text { menangani setiap } \\
\text { urusan di Kantor } \\
\text { ini? }\end{array}$ & 36 & 14 & 72 & 28 \\
\hline 2 & $\begin{array}{l}\text { Bagaimanakah } \\
\text { perasaan anda } \\
\text { terhadap keramah } \\
\text { tambahan dan } \\
\text { kesopanan para } \\
\text { petugas pemberi } \\
\text { pelayanan pada } \\
\text { setiap urusan di } \\
\text { Kantor ini? }\end{array}$ & 39 & 11 & 78 & 22 \\
\hline 3 & $\begin{array}{l}\text { Bagaimanakah } \\
\text { perasaan anda } \\
\text { terhadap sikap } \\
\text { tanggap para } \\
\text { petugas pemberi } \\
\text { pelayanan pada } \\
\text { setiap urusan di } \\
\text { Kantor ini? } \\
\end{array}$ & 33 & 17 & 66 & 34 \\
\hline
\end{tabular}

Sumber: Lampiran 3, Tabulasi Tabel B Nomor 4

Dari 50 orang responden yang menjadi sampel penelitian, sebagaimana ditunjukkan pada tabel hasil penelitian di atas, dapat diketahui bahwa:

a. Sebanyak $72 \%$ diantaranya memberikan pernyataan sudah merasa puas terhadap kemudahan untuk menemukan para petugas yang bertanggung jawab menangani setiap urusan di Kantor ini, sedangkan sisanya hanya $28 \%$ diantaranya memberikan pernyataan tidak puas.

b. Sebanyak $78 \%$ diantara para responden tersebut memberikan pernyataan sudah puas terhadap keramah tambahan dan kesopanan para petugas pemberi pelayanan di Kantor ini dan sisanya hanya $22 \%$ diantaranya menyatakan tidak kpuas.

c. Sebanyak $66 \%$ diantara para responden tersebut memberikan pernyataan sudah merasa puas terhadap sikap tanggap para petugas pemberi pelayanan pada setiap urusan di Kantor ini, dan sisanya 34\% diantaranya menyatakan tidak puas.

5) Dilihat dari Variabel Kepuasan Terhadap Jaminan Keamanan dan Kenyamanan Pelayanan

Dalam mengamati rasa puas dan tidak puasnya pengguna pelayanan terhadap variabel jaminan keamanan dan kenyamanan pelayanan, ada lima aspek yang dijadikan standar penilaian, yaitu: 1) 1) aspek ketersediaan ruang tunggu yang nyaman, 2) aspek ketersediaan tempat parkir yang aman, 3) aspek ketersediaan bukti-bukti tanda terima penolakan ataupun persetujuan pemrosesan berkas, 4) aspek bukti tanda terima pembayaran dan 5) aspek hasil penyelesaian urusan yang telah dapat terbebaskan dari kesalahan. Hasil pengamatannya adalah seperti tersebut pada tabel di bawah ini.

Tabel 9

Pernyataan Kepuasan Responden TerhadapJaminan Keamanan dan Kenyamanan Pelayanan

\begin{tabular}{|c|l|c|c|c|c|}
\hline \multirow{2}{*}{ No } & \multirow{2}{*}{ Aspek yang Dinilai } & \multicolumn{2}{|c|}{$\begin{array}{c}\text { Jawaban } \\
\text { (orang) }\end{array}$} & \multicolumn{2}{c|}{ Persentase } \\
\cline { 3 - 6 } & & Ya & Tdk & Ya & Tdk \\
\hline 1 & $\begin{array}{l}\text { Bagaimanakah } \\
\text { perasaan anda } \\
\text { terhadap } \\
\text { ketersediaan ruang } \\
\text { tunggu yang } \\
\text { nyaman bagi } \\
\text { pengguna pelayanan } \\
\text { di Kantor ini? }\end{array}$ & 39 & 11 & 78 & 22 \\
\hline 2 & $\begin{array}{l}\text { Bagaimanakah } \\
\text { perasaan anda } \\
\text { terhadap } \\
\text { ketersediaan tempat } \\
\text { parkir yang aman } \\
\text { bagi pengguna } \\
\text { pelayanan di Kantor } \\
\text { ini }\end{array}$ & 38 & 12 & 76 & 24 \\
\hline
\end{tabular}




\begin{tabular}{|c|l|l|l|l|l|}
\hline 3 & $\begin{array}{l}\text { Bagaimanakah } \\
\text { perasaan anda } \\
\text { terhadap bukti-bukti } \\
\text { tanda terima, } \\
\text { sebagai tanda } \\
\text { penolakan berkas } \\
\text { ataupun persetujuan } \\
\text { pemrosesan berkas } \\
\text { yang diberkan oleh } \\
\text { Kantor ini? }\end{array}$ & 13 & 37 & 26 & 74 \\
\hline 4 & $\begin{array}{l}\text { Bagaimanakah } \\
\text { perasaan anda } \\
\text { terhadap bukti tanda } \\
\text { terima pembayaran } \\
\text { yang diberikan oleh } \\
\text { Kantor ini? }\end{array}$ & 15 & 35 & 30 & 70 \\
\hline 5 & $\begin{array}{l}\text { Bagaimanakah } \\
\text { perasaan anda } \\
\text { terhadap hasil } \\
\text { penyelesaian urusan } \\
\text { yang diberikan oleh } \\
\text { Kantor ini dapat } \\
\text { terbebaskan dari } \\
\text { kesalahan? }\end{array}$ & 22 & 28 & 44 & 56 \\
\hline
\end{tabular}

Sumber: Lampiran 3, Tabulasi Tabel B Nomor 5

Dari 50 orang responden yang menjadi sampel penelitian, sebagaimana ditunjukkan pada tabel hasil penelitian di atas, dapat diketahui bahwa:

a. Sebanyak $78 \%$ diantaranya memberikan pernyataan sudah merasa puas terhadap ketersediaan ruang tunggu yang nyaman bagi pengguna pelayanan di Kantor ini, sedangkan sisanya hanya $22 \%$ diantaranya memberikan pernyataan tidak puas.

b. Sebanyak $76 \%$ diantara para responden tersebut memberikan pernyataan sudah puas terhadap ketersediaan tempat parkir yang aman bagi pengguna pelayanan di Kantor ini ini dan sisanya hanya $24 \%$ diantaranya menyatakan tidak kpuas.

c. Sebanyak $26 \%$ diantara para responden tersebut memberikan pernyataan sudah merasa puas terhadap bukti-bukti tanda terima, sebagai tanda penolakan berkas ataupun persetujuan pemrosesan berkas yang diberikan oleh Kantor ini, dan sisanya $74 \%$ diantaranya menyatakan tidak puas.

d. Sebanyak 30\% diantara para responden tersebut memberikan pernyataan sudah merasa puas terhadap bukti tanda terima pembayaran yang diberikan oleh Kantor ini, dan sisanya 70\% diantaranya menyatakan tidak puas. e. Sebanyak $44 \%$ diantara para responden tersebut memberikan pernyataan sudah merasa puas terhadap hasil penyelesaian urusan yang diberikan oleh Kantor ini dapat terbebaskan dari kesalahan, dan sisanya $56 \%$ diantaranya menyatakan tidak puas.

\section{PENUTUP}

\section{Simpulan}

a. Dilihat dari variabel kualitas pelayanan publik di Kantor Kepala Desa Candikuning, Kecamatan Baturiti, Kabupaten Tabanan dapat dikatakan telah memenuhi persyaratan sebagai pelayanan berkualitas.

b. Dilihat dari variabel kepuasan pelanggan pelayanan publik di Kantor Kepala Desa Candikuning, Kecamatan Baturiti, Kabupaten Tabanan belum dapat memenuhi kepuasan pelanggan sebagai pengguna pelayanan.

Dengan demikian dikatakan pelayanan di Kantor Kepala Desa Candikuning, Kecamatan Baturiti Kabupaten Tabanan adalah pelayanan yang belum memenuhi kualitas pelayanan.

\section{Saran}

a. Keterbukaan informasi tentang persyaratan administrasi teknis dan administrasi keuangan dalam memberikan pelayanan masih perlu mendapatkan perhatian.

b. Persyaratan administrasi teknis pada setiap urusan masih perlu mendapat perhatian.

c. Keterbukaan informasi tentang kepastian waktu penyelesaian pada setiap urusan masih perlu mendapat perhatian.

d. Ketepatan waktu penyelesaian pada setiap urusan masih perlu mendapat perhatian.

e. Bukti-bukti tanda terima sebagai tanda penolakan berkas ataupun persetujuan pemrosesan berkas bagi pengguna pelayanan masih perlu mendapat perhatian.

f. Bukti tanda terima pembayaran bagi pengguna pelayanan masih perlu mendapatkan perhatian dan

g. Hasil penyelesaian setiap urusan yang diterima oleh pengguna pelayanan masih perlu mendapatkan perhatian. 


\section{DAFTAR PUSTAKA}

Faisal, Sanafiah, 1989, Penelitian Sederhana, Penerbit Yayasan Asah Asih Asuh (YA3) Malang.

Gorda, 1994, Metodologi Penelitian Ilmu Sosial Ekonomi, Penerbit Widya Karya Gematika, Denpasar.

Islamy, M. Irfan, 1998, Pidato pengukuhan Guru Besarnya di Universitas Brawijaya
Keputusan Mentri Negara Pendayagunaan Aparatur Negara, Nomor 81 Tahun 1993, Tentang Pedoman Pelaksanaan Pelayanan Umum.

Merta, I Nengah, 2000, Studi tentang Kualitas Pelayanan Publik.

Moenir H.A.S., 2001, Pelayanan Umum di Indonesia, Cetakan Kelima, PT. Bumi Aksara, Jakarta.

Nurdjaman, dkk, 2004, Modul Pelayanan Prima Lembaga Pelayanan Terpadau Satu Atap. 